\title{
Tissue proteomics outlines AGR2 AND LOX5 as markers for biochemical recurrence of prostate cancer
}

\author{
Giovanny Rodríguez-Blanco ${ }^{1, *}$, Lona Zeneyedpour ${ }^{1, *}{ }^{,}$Diederick Duijvesz ${ }^{2, *}$, A. \\ Marije Hoogland ${ }^{3}$, Esther I. Verhoef ${ }^{3}$, Charlotte F. Kweldam ${ }^{3}$, Peter C. Burgers ${ }^{1}$, \\ Peter Sillevis Smitt ${ }^{1}$, Chris H. Bangma ${ }^{2}$, Guido Jenster ${ }^{2}$, Geert J.L.H. van Leenders ${ }^{3}$, \\ Lennard J.M. Dekker ${ }^{1}$ and Theo M. Luider ${ }^{1}$ \\ ${ }^{1}$ Department of Neurology, Erasmus Medical Centre, Rotterdam, The Netherlands \\ ${ }^{2}$ Department of Urology, Erasmus Medical Centre, Rotterdam, The Netherlands \\ ${ }^{3}$ Department of Pathology, Erasmus Medical Centre, Rotterdam, The Netherlands \\ * These authors have contributed equally to this work \\ Correspondence to: Theo M. Luider, email: t.luider@erasmusmc.nl \\ Keywords: prostate cancer; mass spectrometry; arachidonic acid \\ Received: August 13, $2018 \quad$ Accepted: October 21, 2018 \\ Published: November 23, 2018 \\ Copyright: Rodríguez-Blanco et al. This is an open-access article distributed under the terms of the Creative Commons Attribution \\ License 3.0 (CC BY 3.0), which permits unrestricted use, distribution, and reproduction in any medium, provided the original author \\ and source are credited.
}

\section{ABSTRACT}

Although many patients are cured from prostate cancer ( $\mathrm{PCa}$ ) by surgery only, there are still patients who will experience rising prostate-specific antigen (PSA) levels after surgery, a condition known as biochemical recurrence (BCR). Novel protein prognostic markers in PCa tissue might enable finding better treatment for those patients experiencing BCR with a high chance of metastasis. In this study, we aimed to identify altered proteins in prostate cancer tissue, and to evaluate their potential role as prognostic markers. We used two proteomics strategies to analyse 34 prostate tumours (PCa) and 33 normal adjacent prostate (NAP) tissues. An independent cohort of 481 samples was used to evaluate the expression of three proteins: AGR2, FASN and LOX5 as prognostic markers of the disease. Tissue microarray immunohistochemical staining indicated that a low percentage of positive tumour cells for AGR2 (HR (95\% CI) $=0.61(0.43-0.93)$ ), and a low percentage of positive tumour cells for LOX5 expression (HR $(95 \% \mathrm{CI})=2.53(1.23-5.22)$ ) are predictors of BCR after RP. In contrast, FASN expression had no prognostic value for $\mathrm{PCa}$.

\section{INTRODUCTION}

Prostate cancer $(\mathrm{PCa})$ remains to date the most commonly diagnosed cancer in men in the Western world [1]. Although many patients are cured from this disease after radical prostatectomy (RP) [2], one third of patients will show an increment in serum PSA levels -also known as biochemical recurrence (BCR)-[3]. For those patients, more frequent follow-up and adjuvant therapies are often required to limit progression of the disease $[3,4]$. There is a high need for robust molecular markers that can distinguish indolent cases of $\mathrm{PCa}$ from those that will recur after initial treatment $[3,4]$.

Small molecules, such as metabolites and lipids, have been associated with the progression of different types of cancer, including PCa [5]. In our previous study, using a LC-MS/MS-based targeted metabolomics method, we found lower concentrations of arachidonic acid (AA) in serum from $\mathrm{PCa}$ patients in the most aggressive stage of the disease [6]. In addition, serum levels of hydroxyeicosatetraenoic acid (HETE) metabolites, which are produced by lipoxygenase-type enzymes from AA, were elevated in serum of part of the patients within the same group of advanced PCa [6]. At tissue level, it has been reported that levels of AA in PCa were significantly lower compared to benign prostate tissues [7]. In addition, Yang et al. analysed PCa core biopsies and they found that the 15-LOX-2 metabolite 15-HETE, was higher in PCa than in the normal cores [8]. These findings suggest that the AA pathway might play an important role in 
PCa development and progression. However, analysis of proteins of the AA pathway in $\mathrm{PCa}$, as well as their role in the prognosis of $\mathrm{PCa}$ is still unknown. In this study, we used two complementary mass spectrometry approaches to identify differentially expressed proteins in PCa tissue that could be used as prognostic markers for this disease. Protein signatures were validated in an extended cohort using immunohistochemistry on archival PCa tissue and an available tissue microarray. The expression of the selected proteins was evaluated for prediction of biochemical recurrence after radical prostatectomy.

\section{RESULTS}

\section{Proteomics}

In this study we aimed to find protein signatures of PCa with potential applicability towards prognosis of the disease. To identify differentially expressed proteins in $\mathrm{PCa}$, we used shotgun proteomics using the protein fraction from RNA-bee isolation of $34 \mathrm{PCa}$ and $33 \mathrm{NAP}$ tissues (Figure 1). Using label free quantification (LFQ), a total of 2865 proteins were identified, and 798 proteins were statistically significant $(\mathrm{FDR}<0.01)$. Figure $2 \mathrm{~A}$ illustrates the LFQ mean ratio between PCa and NAP, also indicating that an elevated number of proteins were up-regulated in PCa. The list of identified proteins as well as the differentially expressed proteins in $\mathrm{PCa}$ is presented in Supplementary Table 2. Two proteins, anterior gradient 2, AGR2, and fatty acid synthase, FASN, were highly up-regulated in $\mathrm{PCa}$ and their normalised abundances showed also a trend when compared with the Gleason score, as shown in Figure 2B-2C. These two proteins were considered for further analysis.

To analyse whether proteins in the Arachidonic acid (AA) pathway could be used as prognostic markers for PCa, we manually searched the list of differentially expressed proteins and compared this list with the list of 79 proteins in the AA pathway as described by Sabidó et al. [9] (Supplementary Table 3). Interestingly, we identified fifteen proteins of the AA pathway in the list of de-regulated proteins, and particularly, prostaglandin E synthase 3 . TEBP, showed a degree of correlation with the Gleason score, as is shown in Figure 2D.

We previously reported high levels of HETE metabolites in serum from PCa patients. In our shotgun proteomics dataset we only identified one lipoxygenasetype enzyme deregulated in PCa tissue: LX15B, but its expression is higher in NAP and the statistical test is significant $(p<0.05)$, as shown in Figure 2E. The deregulated proteins in $\mathrm{PCa}$ which are part of the AA pathway are presented in Figure 2A.

Gleason score, pT Stage and ERG oncogene status have been associated with poor prognosis of PCa. To evaluate whether proteins identified in PCa tissue could be associated with these clinical parameters, we performed statistically tests on patients with different Gleason scores (GS 6 vs. GS 7), different pT stages (pT2, pT3, pT3) and whether ERG is activated or not (ERG oncogene-positive vs. ERG oncogene-negative). We did not find statistically significant proteins when comparing Gleason score or pT stage, but we found that 15 proteins were statistically

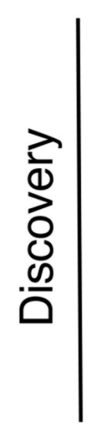

\section{RNA bee isolation}
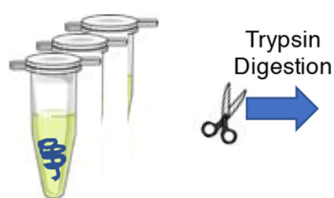

$n=33 \mathrm{NAP}, \mathrm{n}=34 \mathrm{PCa}$

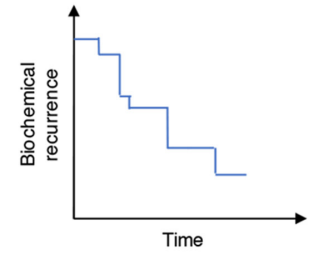

Assessment for prognostic markers of $\mathrm{PCa}$

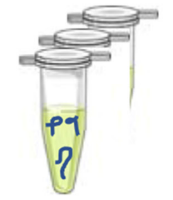

nLCMS/MS

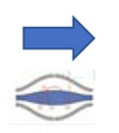

Orbitrap

Q-Exactive+

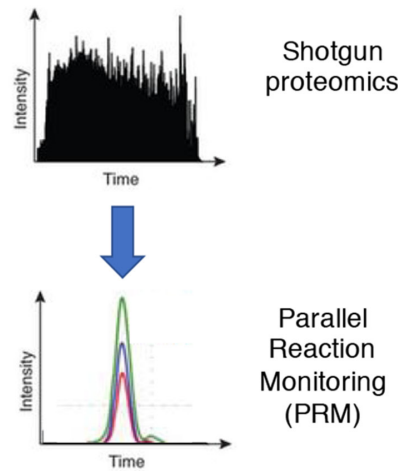

Tissue microarray
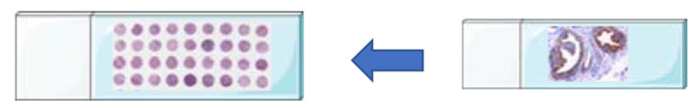

Immunological staining on selected proteins

$\mathrm{n}=481 \mathrm{PCa}$

ERSPC cohort

Figure 1: Workflow for finding proteins in PCa tissue that relate to prediction of biochemical recurrence. 
significant when comparing ERG activation. Interestingly, three of these proteins belonging to the AA pathway and were up-regulated $(\mathrm{FDR}<0.01)$ : phospholipase A2, PA2GA, arachidonate 15-lipoxygenase B, LX15B, and prostaglandin reductase 1, PTGR1. The list of differentially expressed proteins when ERG is activated is presented in Supplementary Table 4. These results indicate that the AA pathway might play a role in ERG activation.

To validate the results obtained in the shotgun proteomics experiment, we performed parallel reaction monitoring measurements (PRM) on the same samples described above, and we included other proteins not identified by shotgun approach in order to evaluate their potential as prognostic markers for PCa. We selected these proteins (Table 1) because they are involved in the metabolism of small molecules and fatty acids (polyamines, eicosanoids and phospholipids), as well as in the so-called Warburg effect, which also involves metabolic enzymes of metabolites present in the TCA cycle $[10,11]$. In total we analysed 18 proteins and each protein was quantified using two peptides. We included two peptides for PARK7, a protein recently described for normalisation of proteomics experiments [12], and as expected, peak areas between samples were not statistically significant $(\mathrm{p}>0.05)$ different.

AMACR, a known marker for $\mathrm{PCa}$, and one of the proteins with the highest fold change and statistical significant different in the shotgun experiments, was included as positive control for the PRM measurements. ANOVA comparison between NAP and PCa at different Gleason Scores indicated a high up-regulation in $\mathrm{PCa}$ $(\mathrm{p}<0.0001)$ for AMACR, confirming the validity of our PRM set up. We could also confirm the shotgun results of AGR2 and FASN proteins using PRM, in both cases the peak area and the Gleason score correlated well. A summary of the statistical calculations performed for the 18 proteins analysed by PRM is presented in Supplementary Table 5.

To validate the importance of the AA pathway in $\mathrm{PCa}$ and its possible application in prognosis, we analysed seven AA pathway proteins by PRM. We included LOX5 as it is involved in the production of eicosanoid-like compounds, and it was not identified by shotgun. Statistical analysis presented in Supplementary Table 5 indicated that LOX5 and TEBP are highly upregulated in $\mathrm{PCa}$ tissue and they are also correlate with the Gleason score. On the other hand, LX15B, HYES, PGH1 were down-regulated (ANOVA, $\mathrm{p}<0.001)$ and LKHA4 and FAAH were not different when compared with the Gleason score.

To identify whether selected proteins involved in metabolic reprogramming (Warburg effect) are deregulated in $\mathrm{PCa}$, we included transitions for another seven proteins in the PRM setup. Interestingly, the ANOVA test indicated that ACSL3, GLSK, LDHA, LDHB and ANM1 proteins are statistically significant $(\mathrm{p}<0.001)$.
A

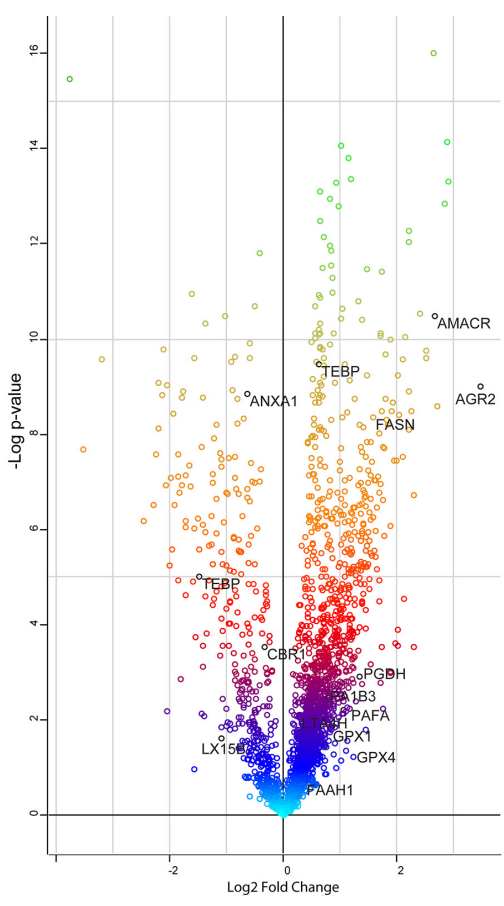

B

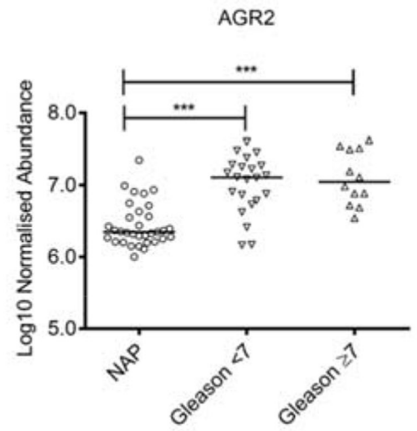

D

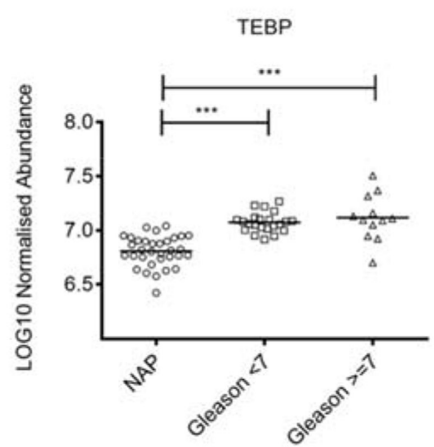

C

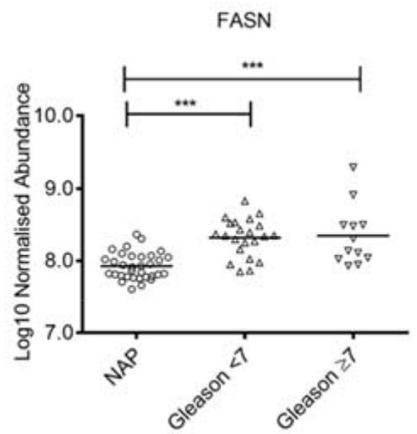

E

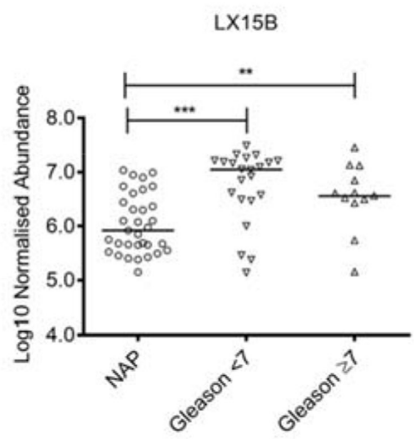

Figure 2: (A) Scatter plot of the normalized abundance mean ratio between PCa ( $=34)$ and NAP ( $=33$ ) using the shotgun approach. Proteins belonging to the AA pathway arepresented in red (upregulated) and blue (down-regulated). (B-E) Boxplots of normalized abundances at different Gleason scores for proteins AGR2, FASN, TEBP and LX15B. 
Table 1: List of transitions used in the Parallel Reaction Monitoring (PRM) experiments

\begin{tabular}{|c|c|c|c|c|c|c|c|}
\hline \multirow[b]{2}{*}{ Gene Name } & \multirow{2}{*}{$\begin{array}{l}\text { Protein name and } \\
\text { accession }\end{array}$} & \multirow[b]{2}{*}{ Peptide } & \multirow[b]{2}{*}{$\mathbf{m} / \mathbf{z}$} & \multirow[b]{2}{*}{$\mathbf{z}$} & RT & RT & \multirow{2}{*}{$\begin{array}{c}\text { HCD } \\
\text { Collision } \\
\text { Energy } \\
(\%)\end{array}$} \\
\hline & & & & & start (min) & stop (min) & \\
\hline \multirow[t]{2}{*}{ LOX5 } & $\begin{array}{l}\text { Arachidonate } \\
\text { 5-lipoxygenase }\end{array}$ & DDGLLVWEAIR & 643.8406 & 2 & 46.13 & 48.13 & 27 \\
\hline & $\begin{array}{c}\text { P09917 } \\
\text { (LOX5_HUMAN) }\end{array}$ & GVVTIEQIVDTLPDR & 827.9542 & 2 & 45.5 & 47.5 & 27 \\
\hline \multirow[t]{2}{*}{ GLS } & Glutaminase & GSTHPQPGVSPPAAPAAPGPK & 641.0024 & 3 & 10.69 & 12.69 & 27 \\
\hline & $\begin{array}{c}\text { O94925 } \\
\text { (GLSK_HUMAN) }\end{array}$ & YAIAVNDLGTEYVHR & 574.2933 & 3 & 25.63 & 27.63 & 27 \\
\hline \multirow[t]{2}{*}{ ALOX15B } & $\begin{array}{c}\text { Arachidonate } \\
\text { 15-lipoxygenase B }\end{array}$ & ELLIVPGQVVDR & 669.393 & 2 & 31.3 & 33.3 & 27 \\
\hline & $\begin{array}{c}\text { O15296 } \\
\text { (LX15B_HUMAN) }\end{array}$ & STGIGIEGFSELIQR & 803.9254 & 2 & 41.27 & 43.27 & 27 \\
\hline \multirow[t]{2}{*}{ LTA4H } & $\begin{array}{c}\text { Leukotriene A-4 } \\
\text { hydrolase }\end{array}$ & LTYTAEVSVPK & 604.3321 & 2 & 18.73 & 20.73 & 27 \\
\hline & $\begin{array}{c}\text { P09960 } \\
\text { (LKHA4_HUMAN) }\end{array}$ & ELVALMSAIR & 551.8181 & 2 & 33.83 & 35.83 & 27 \\
\hline \multirow[t]{2}{*}{ PTGES3 } & $\begin{array}{l}\text { Prostaglandin E } \\
\text { synthase } 3\end{array}$ & LTFSC $[+57.0]$ LGGSDNFK & 723.3401 & 2 & 28.05 & 30.05 & 27 \\
\hline & $\begin{array}{c}\text { Q15185 } \\
\text { (TEBP_HUMAN) }\end{array}$ & LNWLSVDFNNWK & 768.3857 & 2 & 47.25 & 49.25 & 27 \\
\hline \multirow[t]{2}{*}{ ЕРНX2 } & $\begin{array}{c}\text { Bifunctional epoxide } \\
\text { hydrolase } 2\end{array}$ & FLLDTLK & 425.2577 & 2 & 27.61 & 29.61 & 27 \\
\hline & $\begin{array}{c}\text { P34913 } \\
\text { (HYES_HUMAN) }\end{array}$ & AVASLNTPFIPANPNMSPLESIK & 804.4262 & 3 & 43.54 & 45.54 & 27 \\
\hline \multirow[t]{2}{*}{ FAAH } & $\begin{array}{l}\text { Fatty-acid amide } \\
\text { hydrolase } 1\end{array}$ & LQNPDLDSEALLALPLPQLVQK & 805.788 & 3 & 52.9 & 54.9 & 27 \\
\hline & $\begin{array}{c}\text { O00519 } \\
\text { (FAAH1_HUMAN) }\end{array}$ & ELAPEAVLFTYVGK & 768.919 & 2 & 44.96 & 46.96 & 27 \\
\hline \multirow[t]{2}{*}{ ACSL3 } & $\begin{array}{l}\text { Long-chain-fatty- } \\
\text { acid-CoA ligase } 3\end{array}$ & LQAGEYVSLGK & 582.8166 & 2 & 18.53 & 20.53 & 27 \\
\hline & $\begin{array}{c}\text { O95573 } \\
\text { (ACSL3_HUMAN) }\end{array}$ & VLSEAAISASLEK & 659.3666 & 2 & 24.13 & 26.13 & 27 \\
\hline \multirow[t]{2}{*}{ SRM } & Spermidine synthase & LTLHVGDGFEFMK & 498.5868 & 3 & 32.79 & 34.79 & 27 \\
\hline & $\begin{array}{c}19623 \\
\text { (SPEE_HUMAN) }\end{array}$ & ESYYQLMK & 531.2522 & 2 & 19.26 & 21.26 & 27 \\
\hline \multirow[t]{2}{*}{ PRMT1 } & $\begin{array}{c}\text { Protein arginine } \\
\text { N-methyltransferase } 1\end{array}$ & ATLYVTAIEDR & 626.3326 & 2 & 23.36 & 25.36 & 27 \\
\hline & $\begin{array}{c}\text { Q99873 } \\
(\text { ANM1_HUMAN) }\end{array}$ & EVDIYTVK & 483.7608 & 2 & 15.55 & 17.55 & 27 \\
\hline \multirow[t]{2}{*}{ LDHA } & $\begin{array}{c}\text { L-lactate } \\
\text { dehydrogenase A } \\
\text { chain }\end{array}$ & LVIITAGAR & 457.2951 & 2 & 16.05 & 18.05 & 27 \\
\hline & $\begin{array}{c}\text { P00338 } \\
\text { (LDHA_HUMAN) }\end{array}$ & FIIPNVVK & 465.2946 & 2 & 27.24 & 29.24 & 27 \\
\hline PTGS1 & $\begin{array}{l}\text { Prostaglandin } \mathbf{G} / \mathbf{H} \\
\text { synthase } 1\end{array}$ & ILPSVPK & 377.2471 & 2 & 11.8 & 13.8 & $\begin{array}{c}27 \\
\text { (Continued) }\end{array}$ \\
\hline
\end{tabular}




\begin{tabular}{|c|c|c|c|c|c|c|c|}
\hline \multirow[b]{2}{*}{ Gene Name } & \multirow[b]{2}{*}{$\begin{array}{l}\text { Protein name and } \\
\text { accession }\end{array}$} & \multirow[b]{2}{*}{ Peptide } & \multirow[b]{2}{*}{$\mathbf{m} / \mathbf{z}$} & \multirow[b]{2}{*}{$\mathbf{z}$} & RT & RT & \multirow{2}{*}{$\begin{array}{c}\text { HCD } \\
\text { Collision } \\
\text { Energy } \\
(\%)\end{array}$} \\
\hline & & & & & start (min) & stop (min) & \\
\hline & $\begin{array}{c}\text { P23219 } \\
(\text { PGH1_HUMAN) }\end{array}$ & VPDASQDDGPAVERPSTEL & 661.6482 & 3 & 20.46 & 22.46 & 27 \\
\hline & & LILIGETIK & 500.3261 & 2 & 27.45 & 29.45 & 27 \\
\hline \multirow[t]{2}{*}{ FASN } & Fatty acid synthase & LLEQGLR & 414.7505 & 2 & 10.38 & 12.38 & 27 \\
\hline & $\begin{array}{c}\text { P49327 } \\
\text { (FAS_HUMAN) }\end{array}$ & FPQLDSTSFANSR & 735.3546 & 2 & 26.48 & 28.48 & 27 \\
\hline \multirow[t]{2}{*}{ AGR2 } & $\begin{array}{l}\text { Anterior gradient } \\
\text { protein } 2 \text { homolog }\end{array}$ & LPQTLSR & 407.7427 & 2 & 7.16 & 9.16 & 27 \\
\hline & $\begin{array}{c}\text { O95994 } \\
(\text { AGR2_HUMAN) }\end{array}$ & HLSPDGQYVPR & 423.5509 & 3 & 9.3 & 11.3 & 27 \\
\hline \multirow[t]{2}{*}{ PARK7 } & $\begin{array}{c}\text { Protein/nucleic acid } \\
\text { deglycase DJ }\end{array}$ & VTVAGLAGK & 408.2529 & 2 & 10.47 & 12.47 & 27 \\
\hline & $\begin{array}{c}\text { Q99497 } \\
\text { (PARK7_HUMAN) }\end{array}$ & DGLILTSR & 437.7533 & 2 & 17.36 & 19.36 & 27 \\
\hline \multirow[t]{2}{*}{ AMACR } & $\begin{array}{l}\text { Alpha-methylacyl- } \\
\text { CoA racemase }\end{array}$ & LQLGPEILQR & 583.8482 & 2 & 28.39 & 30.39 & 27 \\
\hline & $\begin{array}{c}\text { Q9UHK6 } \\
\text { (AMACR_HUMAN) }\end{array}$ & LAGHDINYLALSGVLSK & 590.9965 & 3 & 34.56 & 36.56 & 27 \\
\hline \multirow[t]{2}{*}{ SMS } & Spermine synthase & HSTLDFMLGAK & 610.3106 & 2 & 23.39 & 25.39 & 27 \\
\hline & $\begin{array}{c}\text { P52788 } \\
\text { (SPSY_HUMAN) }\end{array}$ & YWPTADGR & 483.2274 & 2 & 13.74 & 15.74 & 27 \\
\hline \multirow[t]{2}{*}{ LDHB } & $\begin{array}{c}\text { L-lactate } \\
\text { dehydrogenase B } \\
\text { chain }\end{array}$ & IVVVTAGVR & 457.2951 & 2 & 13.1 & 15.1 & 27 \\
\hline & $\begin{array}{c}\text { P07195 } \\
\text { (LDHB_HUMAN) }\end{array}$ & MVVESAYEVIK & 634.3338 & 2 & 24.62 & 26.62 & 27 \\
\hline
\end{tabular}

Two proteins involved in polyamine metabolism, SMS and SRM, were not different between NAP and PCa, even though this pathway is known to be heavily deregulated in PCa [10].

\section{Immunohistochemistry}

Based on the results of the mass spectrometry experiments we selected four proteins for immunohistochemical (IHC) validation: AGR2, FASN, LOX5 and LX15B. These proteins were selected based on their correlation with the Gleason score and the availability of antibodies. In addition, these antibodies ought to work reliably using formalin-fixed paraffin-embedded (FFPE) tissue. IHC staining of the selected proteins on PCa FFPE tissue sections is shown in Figure 3.

AGR2 showed heterogeneous expression in normal luminal epithelium and PCa. AGR2 staining was strikingly positive in cancer and negative in normal (Figure 3A).
Expression of cytoplasmic FASN was negative to weak and rarely moderate in normal prostate luminal epithelium. Expression in $\mathrm{PCa}$ was stronger $(1+/ 2+)$ than in adjacent normal tissue $(0 / 1+)$ with locally strong expression $(3+)$ in Gleason grade 7 and 9 areas (Figure 3B).

Expression of LX15B was generally moderate to strong $(2+/ 3+)$ and occurred in both cytoplasm and nucleus of both benign luminal cells and PCa. Normal basal epithelium and atrophic prostate epithelium generally showed lower expression $(0 / 1+)$. Stromal expression was negative (0) to weak $(1+)$ (Figure $3 \mathrm{C})$.

LOX5 staining was found to be predominantly expressed in the nuclei and cytoplasm of benign basal epithelial cells and atrophic luminal epithelial cells (1+ to $3+$ ). Normal luminal epithelial cells were generally negative (0) or weakly positive $(1+)$. PCa showed enhanced expressions as compared to benign luminal cells varying from weak to strong, but no clear association with the Gleason score was observed (Figure 3D). 
Table 2A: Clinico-pathologic correlations in the PCa-TMA and AGR2 (percentage of positive tumour cells)

\begin{tabular}{|c|c|c|c|c|}
\hline & Negative & Positive & Total & p-value \\
\hline \multicolumn{5}{|c|}{ PSA at diagnosis } \\
\hline$\leq 10 \mathrm{ng} / \mathrm{ml}$ & $88(21.8 \%)$ & $264(65.3 \%)$ & $352(87.1 \%)$ & 0.141 \\
\hline$>10 \mathrm{ng} / \mathrm{ml}$ & $18(4.4 \%)$ & $34(8.5 \%)$ & $52(12.9 \%)$ & \\
\hline Total & $106(26.2 \%)$ & $298(73.8 \%)$ & 404 & \\
\hline \multicolumn{5}{|l|}{ Gleason score } \\
\hline$<7$ & $44(10.9 \%)$ & $170(42.0 \%)$ & $214(52.9 \%)$ & 0.017 \\
\hline 7 & $51(12.6 \%)$ & $112(27.6 \%)$ & $163(40.2 \%)$ & \\
\hline$>7$ & $11(2.7 \%)$ & $17(4.2 \%)$ & $28(6.9 \%)$ & \\
\hline Total & $106(26.2 \%)$ & $299(73.8 \%)$ & 405 & \\
\hline \multicolumn{5}{|l|}{ pT-stage } \\
\hline pT2 & $68(16.8 \%)$ & $212(52.3 \%)$ & $280(69.1 \%)$ & 0.121 \\
\hline $\mathrm{pT} 3 / 4$ & $38(9.4 \%)$ & $87(21.4 \%)$ & $125(30.9 \%)$ & \\
\hline Total & $106(26.2 \%)$ & $299(73.8 \%)$ & 405 & \\
\hline
\end{tabular}

Positive $=100 \%$ positive cells, Negative $=$ less than $100 \%$ positive tumour cells.

Table 2B: Intensity of positive tumour cells, Negative $=$ weak or no staining, Positive $=$ strong staining intensity

\begin{tabular}{|c|c|c|c|c|}
\hline & Negative & Positive & Total & p-value \\
\hline \multicolumn{5}{|c|}{ PSA at diagnosis } \\
\hline$\leq 10 \mathrm{ng} / \mathrm{ml}$ & $9(2.2 \%)$ & $343(84.9 \%)$ & $352(87.1 \%)$ & 0.203 \\
\hline$>10 \mathrm{ng} / \mathrm{ml}$ & $3(0.8 \%)$ & $49(12.1 \%)$ & $52(12.9 \%)$ & \\
\hline Total & $12(3.0 \%)$ & $392(97.0 \%)$ & 404 & \\
\hline \multicolumn{5}{|l|}{ Gleason score } \\
\hline$<7$ & $2(0.5 \%)$ & $212(52.3 \%)$ & $214(52.8 \%)$ & 0.032 \\
\hline 7 & $8(2.0 \%)$ & $155(38.3 \%)$ & $163(40.3 \%)$ & \\
\hline$>7$ & $2(0.5 \%)$ & $26(6.4 \%)$ & $28(6.9 \%)$ & \\
\hline Total & $12(3.0 \%)$ & $393(97.0 \%)$ & 405 & \\
\hline \multicolumn{5}{|l|}{ pT-stage } \\
\hline $\mathrm{pT} 2$ & $9(2.3 \%)$ & $271(66.9 \%)$ & $280(69.2 \%)$ & 0.465 \\
\hline $\mathrm{pT} 3 / 4$ & $3(0.7 \%)$ & $122(30.1 \%)$ & $125(30.8 \%)$ & \\
\hline Total & $12(3.0 \%)$ & $393(97.0 \%)$ & 405 & \\
\hline
\end{tabular}

\section{Tissue microarray}

To determine whether expression of AGR2, FASN, and LOX5 might correlate with clinical parameters we analysed these proteins in 481 samples from RP patients. Cytoplasmic expression of AGR2 occurred in $84 \%$ (404/481) of the patients, with $52 \%$ of cores showing strong intensity (3+). 74\% (299/404) of the cores exhibited staining in $100 \%$ of tumour cells. Strong FASN staining occurred in $86 \%(399 / 461)$ of patients. We did not find any expression of LOX5 in 54\% of the cores, and both the cytoplasmic and the nuclear intensities were weak (1+) in most cases. The percentage of positive tumour cells stained for LOX 5 was lower than $10 \%$ in the 224 positive cores.

An association between the Gleason score (GS) and the percentage of positive tumour cells and intensity of AGR2 was found $(p=0.017$, and $p=0.032$, respectively, as described in Table 2A-2B). AGR2 expression occurred more often in patients with lower GS (42\% in patients with GS $<7$ when analysing percentage of tumour cells, and $52.3 \%$ when cytoplasm was analysed). FASN 
expression was higher in $\mathrm{GS}<7$ and $\mathrm{GS}=7 \quad(49.0 \%$ and $34.6 \%$ respectively) than in GS $>7(5.4 \%)$, but no correlation existed between FASN and PSA, GS or pT stage (Supplementary Table 6).

A correlation between $\mathrm{pT}$ stage and cytoplasm intensity of LOX5 was found ( $\mathrm{p}=0.044$, in Supplementary Table 7A). No other correlation was found when analysing cytoplasmic intensity, nuclear intensity, or percentage of positive tumour cells for LOX5 (Supplementary Table 7B-7C).

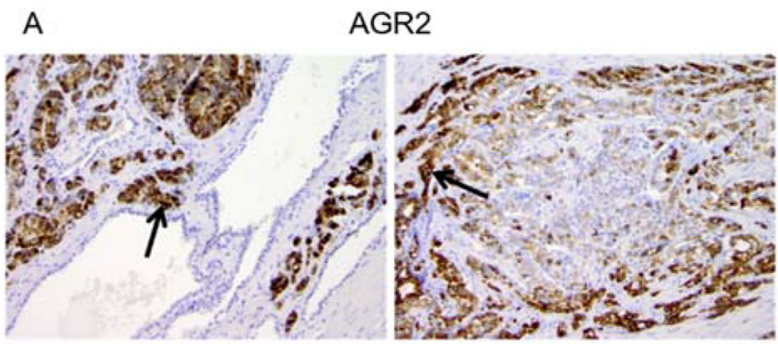

Gleason 6

Gleason 9

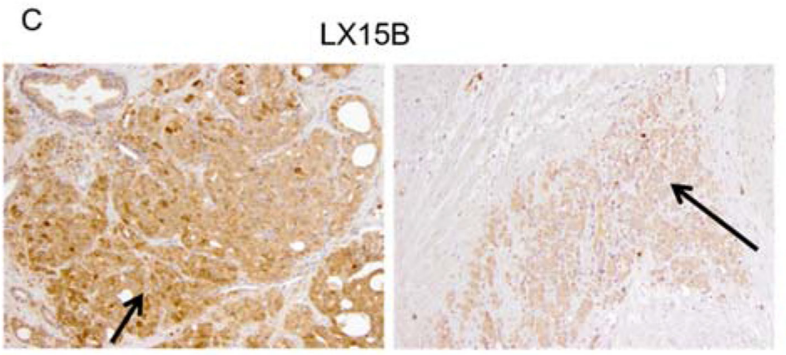

Gleason 8
Gleason 9
We constructed Kaplan Meier (KM) curves to identify the role of AGR and LOX5 in predicting BCR after surgery. We analysed if the percentage of positive cells of AGR2 100\% (positive) or lower than $100 \%$ (any negative) was predictive for BCR. We found that a percentage lower than $100 \%$ of positive tumour cells $(<100 \%)$ in AGR2 was predictive for BCR (HR $(95 \% \mathrm{CI})$ $=0.61(0.43-0.93)) ; p=0.02)$, as described in Table 2 and Figure 4.

B FASN

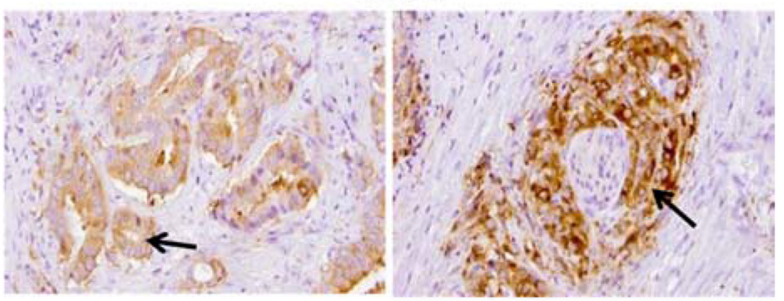

Gleason 7

Gleason 9

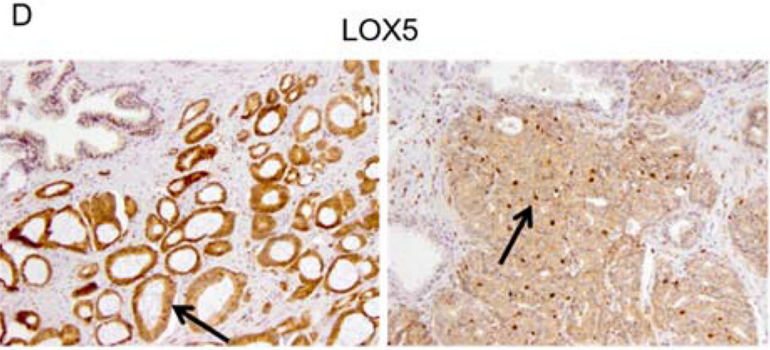

Gleason 6

Figure 3: Immunohistochemical staining in PCa tissue for (A) Anterior Gradient 2 (AGR2) in Gleason score 6 and Gleason score 9 , (B) Fatty Acid Synthase (FASN) in Gleason 7 and Gleason 9, (C) 15-lipoxygenase-2 (LX15B) in Gleason score 8 and Gleason 9 and (D) 5-lipoxygenase (LOX5) Gleason 6 and Gleason 8.
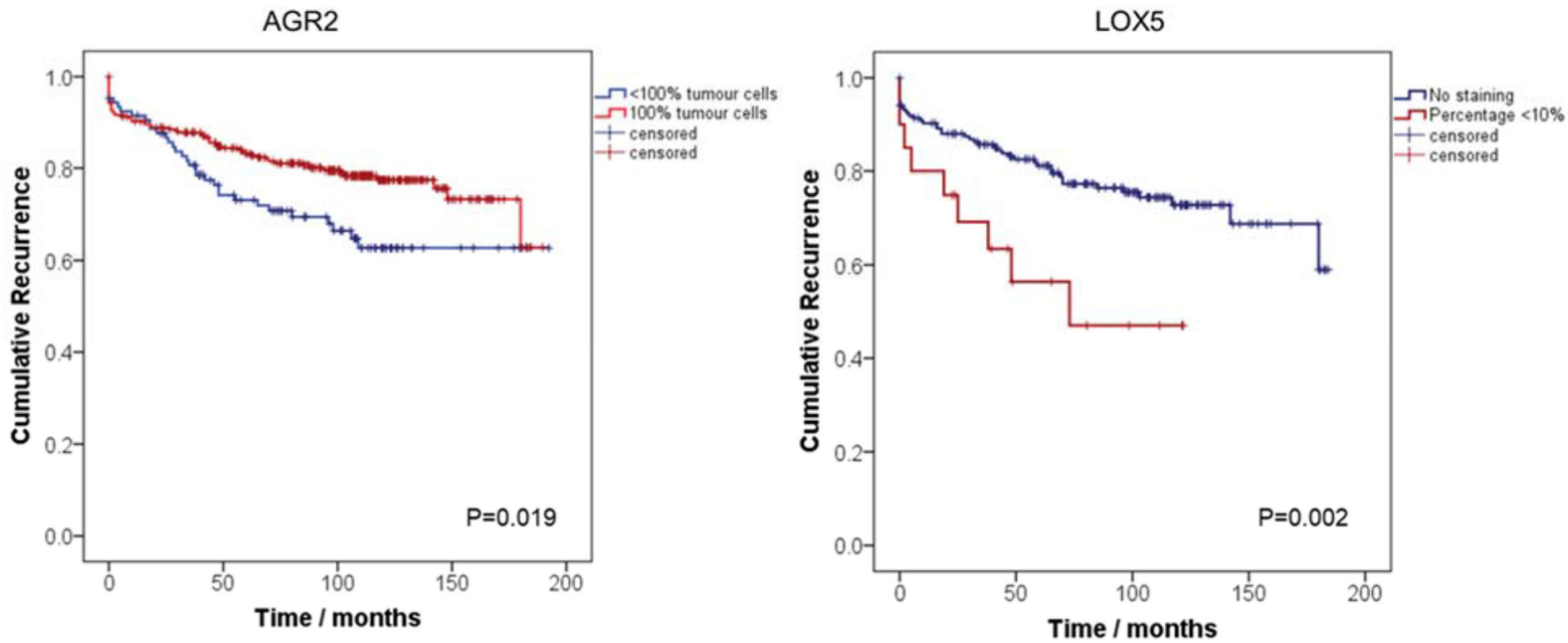

Figure 4: Kaplan-Meier curves assessing the probability of PCa biochemical recurrence after radical prostatectomy by AGR2 and LOX5. Blue lines represent: AGR2: Percentage of tumour cells < 100\% LOX5: No staining. Red lines represent: AGR2: $100 \%$ of positive tumour cells, LOX $5:>0 \%$ staining of positive tumour cells. 
For LOX5, we analysed whether the percentage of positive cells was negative (LOX5 $0 \%$ ), or it had any expression (LOX5 $>0 \%$ ). Expression for LOX5 was characterised by only a small percentage of positive tumour cells, being at maximum $10 \%$. KM curves indicate that low percentage of LOX5 positive tumour cells is a predictor of BCR in comparison with negative staining $(0 \%)$, in a univariate analysis $(\mathrm{HR}(95 \% \mathrm{CI})=2.53(1.23-$ 5.22)); $\mathrm{p}=0.002$ ), as presented in Table 2 and Figure 4.

\section{DISCUSSION}

The Gleason score is an effective indicator of aggressiveness of $\mathrm{PCa}$ and therefore an important parameter to determine prognosis. However, more knowledge of which patients will relapse after radical prostatectomy and/or which patients will respond better to a specific treatment is still needed.

AGR2 is a predictor of biochemical recurrence after performing TMA immunostaining in the Evaluation set (Figure 4), confirming previous reports for this protein as biomarker for PCa [13-15]. Bu et al., demonstrated that AGR2 is overexpressed in PCa, particularly in lowgrade tumours and also in tumour precursor lesions PIN. In addition, high levels of AGR2 transcript were found in urine sediments from PCa patients [16]. Two distinct splice variants of AGR2 in urine exosomes have been identified as effective markers distinguishing NAP and $\mathrm{PCa}$ [17]. AGR2 has been reported to be induced by androgens in PCa [18], and its tumorigenic function is associated with cell growth, survival and metastasis, as recently reviewed [19].

Fatty acid synthase (FASN) is known to be a key enzyme in the production of long chain fatty acids from Acetyl-CoA and Malonyl-CoA [20]. Overexpression of this protein in $\mathrm{PCa}$ tissue has been reported in cell lines [21], tissue microarrays [22], tissue biopsy cores [23] and exosomes [24]. FASN-normalised intensity was high in $\mathrm{PCa}$ in our proteomics dataset and its expression was independently evaluated by immunohistochemistry and a TMA. Although its expression does not predict biochemical recurrence, inhibition of FASN has been proposed as a therapeutic target because of its increased expression and its relation to both cell cycle arrest and apoptosis [25]. Our results reinforce the theory that FASN could be an important target to manipulate the fatty acid and lipid metabolism in cancer and therefore control cancer cell behaviour [26-28].

The AA pathway is a key inflammatory pathway involved in cellular signalling as well as prostate carcinogenesis [29]. Arachidonic acid is stored in cell membranes as a phospholipid, it is released by the action of phospholipase A2-type enzymes, and then metabolised by the action of cyclooxygenases (COX), lipoxygenases (LOX) and P450 cytochromes to produce biologically active eicosanoids [8].
We found that the abundance of lipoxygenase 15 type 2 (LX15B), an enzyme encoded by the gene $A L O X 15 B$, was lower in PCa than in NAP. Evaluation by immunohistochemistry showed a moderate increased abundance in both cytoplasm and nucleus of normal luminal cells and PCa when compared to normal basal epithelium. These results do not support our hypothesis that the previously reported high serum concentration of HETE metabolites could be explained by an up-regulation of this lipoxygenase-type enzyme [6]. Interestingly, low expression of LOX5 in PCa tissue is slightly higher in $\mathrm{PCa}$ compared to NAP, and this expression can be used to evaluate BCR after surgery (Figure 4). In addition, we noticed that expression of upstream enzymes, such as the phospholipases (PA2PA), is higher in $\mathrm{PCa}$ when there is an activation of ERG-oncogene (Supplementary Table 4). These results highlight the importance of the AA pathway in PCa, and, particularly, when ERG is activated. However, functional studies need to be performed in order to analyse the link between ERG activation and the deregulation of enzymes in the AA pathway, as well as the HETE metabolites or other eicosanoid-type fatty acids in the development of PCa.

Association of different enzymes of this family with $\mathrm{PCa}$ has recently been described in literature. Patel et al. [30], studied the expression of cytosolic phospholipase $\mathrm{A}_{2}$ in PCa cells and they reported that increased levels of this enzyme were observed in androgen-insensitive PCa cell lines and they suggested that this enzyme plays a role in cancer cell proliferation and apoptosis. PAFAH (PLA2G7) enzyme was identified by Vainio et al. in a set of 9783 human tissue samples and it was proposed as a potential drug target specially in ERG positive PCa [31]. Validation studies performed by the same group indicated a correlation between staining intensity for PAFAH and Gleason Score in $50 \%$ of the cases, thus suggesting that both enzymes can be seen as biomarkers for $\mathrm{PCa}$, and the PAFAH inhibition by statins as a therapeutic tool for managing the disease [29].

We found that the protein TEBP (PTGES3), was up-regulated in PCa tissue, TEBP protein is involved in eicosanoid signalling as it produces the Prostaglandin $\mathrm{E} 2$, involved in inflammation processes. In addition, it is reported to be an enhancer of androgen receptor activity. It is involved in AR binding to chromatin, which is a critical step in AR signalling and PCa development $[32,33]$. Further validation is still required, using both quantitative mass spectrometry and immunohistochemistry, to confirm a potential role of this protein in $\mathrm{PCa}$ diagnosis and prognosis. In addition, further analysis in-vitro, could address the role of the metabolite prostaglandin $\mathrm{E}$, produced by TEBP along the AA pathway in $\mathrm{PCa}$ development and progression.

Cancer cells demand energy for proliferation and therefore there might be a metabolic reprograming in the cancer progression process (Warburg effect). By using 
both shotgun and PRM experiments, we noticed that some metabolic enzymes are de-regulated in PCa (Supplementary Table 5). It is of interest that the expression of lactate dehydrogenase-A protein (LDHA) was significantly $(p<0.0001)$ lower in PCa than in NAP, and it is also deregulated when ERG is activated (Supplementary Table 4). This result might be associated to previous reports for this protein indicating a key role in PCa oncogenesis [34]. LDHA executes the final step of aerobic glycolysis and has been reported to be involved in tumour progression [35]. It was recently demonstrated that LDHA overexpression is highly linked to local relapse of PCa [36].

In conclusion, the experiments in this study allowed the identification of proteins and pathways associated to $\mathrm{PCa}$. We identified a relationship between proteins in the AA pathway and $\mathrm{PCa}$, and we have shown that expression of LOX5 and AGR2 in tissue predict biochemical recurrence after radical prostatectomy. Further validation studies on independent cohorts using different antibodies are needed to analyse the role of TEBP in PCa progression, as well as their clinical applicability. In addition, functional analyses are still required to fully understand their role in cancer cell proliferation, apoptosis and senescence.

\section{MATERIALS AND METHODS}

\section{Clinical specimens}

\section{Discovery set}

The protein fractions from tissue RNA isolation of 67 samples (33 NAP tissues and 34 PCa tissues) were analysed (MEC-2004-261); PCa samples were previously published (GSE41408) [37], as well as additional cancerous and control samples, accessible via GEO accession number GSE59745 [38]. Clinico-pathologic characteristics of the samples used for proteomics profiling are presented in Supplementary Table 1.

\section{Tissue Microarray (TMA)- evaluation set}

A Tissue Microarray (TMA) was constructed including 481 patients diagnosed with $\mathrm{PCa}$ from the European Randomized Study of Screening for $\mathrm{PCa}$ (ERSPC) [39-41]. All patients had undergone RP in Erasmus MC between 1987 and 2010, without previous radiation or hormonal therapy. Clinical follow-up was recorded after each control visit at our outpatient clinic, and data were transmitted to a central study database. Post-operative biochemical recurrence (BCR) was defined as an increment of $0.2 \mathrm{ng} / \mathrm{mL}$ in serum PSA after two consecutive measurements, with at least three months between measurements. Clinico-pathologic characteristics and follow-up for patients treated by RP are also summarized in Supplementary Table 1.

\section{Sample preparation}

\section{Proteomics}

The protein interface from tissue RNA isolation with RNA-Bee of $67 \mathrm{PCa}$ tissue samples (33 NAP adjacent tissues and $34 \mathrm{PCa}$ ) were kept at $-80{ }^{\circ} \mathrm{C}$. For protein digestion, samples were thawed and $50 \mu \mathrm{L}$ were transferred to a new microcentrifuge tube and precipitated with cold acetone. After spinning down for 10 minutes, the supernatant was removed and the pellet was washed twice with cold acetone. Supernatant was removed and $50 \mu \mathrm{L}$ 0.1\% RapiGest (Waters Corporation, Milford, MA) $50 \mathrm{mM} \mathrm{NH}_{4} \mathrm{HCO}_{3}$ were added to the protein pellet. The protein pellet was dissolved by external sonication for 5 min at $70 \%$ amplitude at a maximum temperature of 25 ${ }^{\circ} \mathrm{C}$ (Digital Sonifier model 450, Branson, Danbury, CT). The proteins were reduced with $10 \mathrm{mM}$ dithiothreitol (DTT) at $60{ }^{\circ} \mathrm{C}$ for $30 \mathrm{~min}$. After the mixture was cooled down to room temperature, it was alkylated in the dark with $50 \mathrm{mM}$ iodoacetamide at ambient temperature for $30 \mathrm{~min}$, and digested overnight with $8 \mu \mathrm{L}$ trypsin $0.1 \mu \mathrm{g} /$ $\mathrm{mL}$ (Promega, Madison, WI). To inactivate trypsin and to degrade the RapiGest, $6 \mu \mathrm{L}$ of 5\% TFA was added and samples were incubated for 30 minutes at $37^{\circ} \mathrm{C}$. Samples were centrifuged at maximum speed for 60 minutes at 4 ${ }^{\circ} \mathrm{C}$ and the supernatant was transferred to a new Eppendorf tube. A fraction of $5 \mu \mathrm{L}$ was then diluted 40 times and subsequently transferred to LC vials for LC-MS analysis.

\section{Chromatography separation and mass spectrometric analysis}

Samples were measured using a nano-LC system (Ultimate 3000, Thermo Fisher Scientific, Amsterdam, the Netherlands) coupled online to Q Exactive plus mass spectrometer (Thermo Fisher Scientific, Bremen, Germany). Chromatographic and mass spectrometry conditions used are described previously [42, 43]. Briefly, $2 \mu \mathrm{L}$ were injected into the nano-LC after preconcentrating and washing of the sample on a C18 trap column (1 $\mathrm{mm} \times 300 \mu \mathrm{m}$ internal diameter) Thermo Fisher Scientific). Peptides were eluted after loading the sample on to a C18 column (PepMap C18, $75 \mu \mathrm{m}$ ID $\times 500$ mm, $2 \mu \mathrm{m}$ particle and $100 \AA$ pore size, Thermo Fisher Scientific) using a linear 90 min gradient $\left(4-25 \%\right.$ acetonitrile $/ \mathrm{H}_{2} \mathrm{O}$; $0.1 \%$ formic acid) at a flow rate of $250 \mathrm{~nL} / \mathrm{min}$. The separation of the peptides was monitored by a UV detector (absorption at $214 \mathrm{~nm}$ ). Data was collected in datadependent acquisition mode (DDA). Full scan MS spectra $(\mathrm{m} / \mathrm{z} 400-1600)$ in profile mode were acquired in the Orbitrap with a resolution of 70,000 after accumulation of an AGC target of $1 \times 10^{6}$ using a maximum fill time of 100 ms. The top 12 peptide signals (charge-state $2^{+}$and higher) were isolated (1.6 Da window) and fragmented by HCD (Higher-energy collision, normalized collision energy 28.0) and measured in the Orbitrap with a AGC target of 
50,000 , a maximum fill time of $60 \mathrm{~ms}$ and a resolution of 17,500. Dynamic exclusion was activated; after the first time a precursor was selected for fragmentation it was excluded for a period of 30 seconds using a relative mass window of $10 \mathrm{ppm}$. Lock mass correction was activated to improve mass accuracy of the survey scan.

Technical replicates of each sample were randomly analysed within the measurement period and no significant changes in the number of identified proteins were observed in time for both the replicates and quality control measurements

\section{Orbitrap-MS/MS data processing and analysis}

Label free Quantitation was performed using MaxQuant software (version 1.5.5.1) [44]. Data was searched against the UniProt-Swiss-Prot 2014-4 database using the Andromeda [45] search engine incorporated in MaxQuant. Cysteine carbamidomethylation was set as fixed modification and methionine oxidation and $\mathrm{N}$-terminal acetylation were set as variable modifications. Peptide and protein identifications were set at a maximum False Discovery rate of 1\%. We used the option "match between runs" option to allow matching identifications across measurements and the minimum number of peptides per proteins required for quantitation was set to 2 .

\section{Parallel reaction monitoring (PRM)}

PRM was performed on a nano-LC Fusion Orbitrap system. We used similar settings to the above-mentioned DDA measurements on the nano-LC, with the difference of an elution gradient of $60 \mathrm{~min}$. A targeted MS/MS method was developed for 37 peptides, as presented in Table 1. A quadrupole isolation window of $1 \mathrm{~m} / \mathrm{z}$ units, an AGC target of 2e5 ions, a maximum fill time of $502 \mathrm{~ms}$ and an orbitrap resolving power of 240,000 at $200 \mathrm{~m} / \mathrm{z}$ were used. A fixed HCD normalized collision energy for all peptides of 27 was used, retention times were determined for all peptides, using multiple injections of a tissue sample in which a signal for all 27 peptides was present. Based on the determined retention times a scheduled method was established using a 3 minutes retention time window for each peptide.

\section{Immunohistochemistry}

Tissue slides $(5 \mu \mathrm{m})$ were mounted on aminoacetylsilane coated glass slides (Statfrost, Berlin, Germany), deparaffinised in xylene and dehydrated in ethanol. Endogenous peroxidase was blocked by $1 \%$ hydrogen peroxide in methanol for $20 \mathrm{~min}$. Samples were pretreated by microwave $(700 \mathrm{~W})$ in TRIS-EDTA pH 9.0 or in citrate buffer $\mathrm{pH} 6.0$ for $15 \mathrm{~min}$. The slides were incubated overnight at $4{ }^{\circ} \mathrm{C}$ with the following primary antibodies targeting anterior gradient protein 2 (AGR2; 1:100; HPA007912, Sigma); fatty acid synthase (FASN; 1:400; ab22759, Abcam, Cambridge, MA, USA); arachidonate 15-lipoxygenase type B (LX15B 1:2000, ab23691, Abcam, Cambridge, MA, USA), and arachidonate 5-lipoxygenase (LOX5; 1:200 ab169755, Abcam, Cambridge, MA, USA) [41]. Chromogenic visualization was performed with the EnVision DAKO Kit (Dako, Glostrup, Denmark). After counterstaining with haematoxylin, slides were thoroughly washed, dehydrated, cleared in xylene and mounted in malinol (Chroma-Geselschaft, Körgen, Germany).

In the tissue microarray, immunohistochemical staining for AGR2, 5-LOX and FASN was visually examined as described previously [46]. Staining intensity was scored as negative ( 0 ; no staining), weak (1+; only visible at high magnification), moderate (2+; visible at low magnification), and strong (3+; striking at low magnification). If there was heterogeneous expression, the strongest intensity was used for further analyses. For AGR2, the percentage of positive tumour cells was counted and used for further analyses. For optimization and validation of all immunohistochemical procedures we used appropriate internal and external controls, and omitted first antibodies to exclude non-specific binding [47].

\section{Statistics}

Protein annotation and statistical testing for differences (two-sided Student's T-test, permutationbased FDR 0.05) in the proteomics shotgun experiments was performed in Perseus [48]. Protein normalised intensities were $\log 2$ transformed before testing. The PRM data were analysed using Skyline version 3.5.0.9320 MacCoss Lab Software, Seattle, WA; https:// skyline.gs.washington.edu/labkey/project/home/software/ Skyline/begin.view), fragment ions for each targeted mass were extracted and peak areas were integrated. Data matrix from PRM experimenst was processed in GraphPad Prism 5 for Windows and R version 3.2.3. One-way Analysis of Variance (ANOVA) allowing multiple comparisons was used to estimate differences among Gleason score groups.

Associations between clinico-pathologic parameters and protein expression in TMA experiments were performed by student $t$-test or chi-squared test. Survival curves were calculated according Kaplan-Meier (KM), and to detect significant survival differences the Log-Rank test was used. Univariate and multivariate Cox regression were used to determine predictive properties of AGR2, LOX5 and FASN for BCR. A two-sided $p$-value of $\leq 0.05$ was considered significant. Statistical analysis for the TMA expression was performed in SPSS version 22.

\section{ACKNOWLEDGMENTS AND FUNDING}

This work was financially supported by the Prostate Research Organizations-Network of Early Stage Training 
(PRO-NEST) - FP7 Marie Curie initial training network (Grant Agreement No. 238278), and by the framework of CTMM, the Centre for Translational Molecular Medicine, PCMM (grant 03O-203-1). GR-B thanks Dr Nerea Alonso for her support on data analysis and manuscript preparation.

\section{CONFLICTS OF INTEREST}

The authors declare no conflicts of interest.

\section{REFERENCES}

1. Malvezzi M, Bertuccio P, Levi F, La Vecchia C, Negri E. European cancer mortality predictions for the year 2013. Ann Oncol. 2013; 24:792-800. https://doi.org/10.1093/ annonc/mdt010.

2. Kachroo N, Gnanapragasam VJ. The role of treatment modality on the utility of predictive tissue biomarkers in clinical prostate cancer: a systematic review. J Cancer Res Clin Oncol. 2013; 139:1-24. https://doi.org/10.1007/ s00432-012-1351-7.

3. Pound CR, Partin AW, Eisenberger MA, Chan DW, Pearson JD, Walsh PC. Natural history of progression after PSA elevation following radical prostatectomy. JAMA. 1999; 281:1591-97. https://doi.org/10.1001/jama.281.17.1591.

4. Uchio EM, Aslan M, Wells CK, Calderone J, Concato J. Impact of biochemical recurrence in prostate cancer among US veterans. Arch Intern Med. 2010; 170:1390-95. https:// doi.org/10.1001/archinternmed.2010.262.

5. Sreekumar A, Poisson LM, Rajendiran TM, Khan AP, Cao Q, Yu J, Laxman B, Mehra R, Lonigro RJ, Li Y, Nyati MK, Ahsan A, Kalyana-Sundaram S, et al. Metabolomic profiles delineate potential role for sarcosine in prostate cancer progression. Nature. 2009; 457:910-14. https://doi. org/10.1038/nature07762. Erratum in: Nature. $2013 \mathrm{Jul}$ 25;499(7459):504.

6. Rodríguez-Blanco G, Burgers PC, Dekker LJ, Ijzermans JJ, Wildhagen MF, Schenk-Braat EA, Bangma CH, Jenster G, Luider TM. Serum levels of arachidonic acid metabolites change during prostate cancer progression. Prostate. 2014; 74:618-27. https://doi.org/10.1002/pros.22779.

7. Schumacher MC, Laven B, Petersson F, Cederholm T, Onelöv E, Ekman P, Brendler C. A comparative study of tissue $\omega-6$ and $\omega-3$ polyunsaturated fatty acids (PUFA) in benign and malignant pathologic stage pT2a radical prostatectomy specimens. Urol Oncol. 2013; 31:318-24. https://doi.org/10.1016/j.urolonc.2011.01.014.

8. Yang P, Cartwright CA, Li J, Wen S, Prokhorova IN, Shureiqi I, Troncoso P, Navone NM, Newman RA, Kim J. Arachidonic acid metabolism in human prostate cancer. Int J Oncol. 2012; 41:1495-503. https://doi.org/10.3892/ ijo.2012.1588.
9. Sabidó E, Quehenberger O, Shen Q, Chang CY, Shah I, Armando AM, Andreyev A, Vitek O, Dennis EA, Aebersold R. Targeted proteomics of the eicosanoid biosynthetic pathway completes an integrated genomicsproteomics-metabolomics picture of cellular metabolism. Mol Cell Proteomics. 2012; 11:M111.014746. https://doi. org/10.1074/mcp.M111.014746.

10. Zabala-Letona A, Arruabarrena-Aristorena A, MartínMartín N, Fernandez-Ruiz S, Sutherland JD, Clasquin M, Tomas-Cortazar J, Jimenez J, Torres I, Quang P, Ximenez-Embun P, Bago R, Ugalde-Olano A, et al. mTORC1-dependent AMD1 regulation sustains polyamine metabolism in prostate cancer. Nature. 2017; 547:109-13. https://doi.org/10.1038/nature22964.

11. Vander Heiden MG, Cantley LC, Thompson CB. Understanding the Warburg effect: the metabolic requirements of cell proliferation. Science. 2009; 324:102933. https://doi.org/10.1126/science.1160809.

12. Wiśniewski JR, Mann M. A Proteomics Approach to the Protein Normalization Problem: Selection of Unvarying Proteins for MS-Based Proteomics and Western Blotting. J Proteome Res. 2016; 15:2321-26. https://doi.org/10.1021/ acs.jproteome.6b00403.

13. Kani K, Malihi PD, Jiang Y, Wang H, Wang Y, Ruderman DL, Agus DB, Mallick P, Gross ME. Anterior gradient 2 (AGR2): blood-based biomarker elevated in metastatic prostate cancer associated with the neuroendocrine phenotype. Prostate. 2013; 73:306-15. https://doi. org/10.1002/pros.22569.

14. Ho ME, Quek SI, True LD, Morrissey C, Corey E, Vessella RL, Dumpit R, Nelson PS, Maresh EL, Mah V, Alavi M, Kim SR, Bagryanova L, et al. Prostate cancer cell phenotypes based on AGR2 and CD10 expression. Mod Pathol. 2013; 26:849-59. https://doi.org/10.1038/ modpathol.2012.238.

15. Zhang JS, Gong A, Cheville JC, Smith DI, Young CY. AGR2, an androgen-inducible secretory protein overexpressed in prostate cancer. Genes Chromosomes Cancer. 2005; 43:249-59. https://doi.org/10.1002/ gcc.20188.

16. Bu H, Bormann S, Schäfer G, Horninger W, Massoner P, Neeb A, Lakshmanan VK, Maddalo D, Nestl A, Sültmann $\mathrm{H}$, Cato AC, Klocker H. The anterior gradient 2 (AGR2) gene is overexpressed in prostate cancer and may be useful as a urine sediment marker for prostate cancer detection. Prostate. 2011; 71:575-87. https://doi.org/10.1002/ pros. 21273.

17. Neeb A, Hefele S, Bormann S, Parson W, Adams F, Wolf P, Miernik A, Schoenthaler M, Kroenig M, Wilhelm K, Schultze-Seemann W, Nestel S, Schaefer G, et al. Splice variant transcripts of the anterior gradient 2 gene as a marker of prostate cancer. Oncotarget. 2014; 5:8681-89. https://doi.org/10.18632/oncotarget.2365. 
18. $\mathrm{Bu} \mathrm{H}$, Schweiger MR, Manke $\mathrm{T}$, Wunderlich A, Timmermann B, Kerick M, Pasqualini L, Shehu E, Fuchsberger C, Cato AC, Klocker H. Anterior gradient 2 and 3-two prototype androgen-responsive genes transcriptionally upregulated by androgens and by oestrogens in prostate cancer cells. FEBS J. 2013; 280:1249-66. https://doi.org/10.1111/febs.12118.

19. Brychtova V, Mohtar A, Vojtesek B, Hupp TR. Mechanisms of anterior gradient-2 regulation and function in cancer. Semin Cancer Biol. 2015; 33:16-24. https://doi. org/10.1016/j.semcancer.2015.04.005.

20. Yoshii Y, Furukawa T, Oyama N, Hasegawa Y, Kiyono Y, Nishii R, Waki A, Tsuji AB, Sogawa C, Wakizaka H, Fukumura T, Yoshii H, Fujibayashi Y, et al. Fatty acid synthase is a key target in multiple essential tumor functions of prostate cancer: uptake of radiolabeled acetate as a predictor of the targeted therapy outcome. PLoS One. 2013; 8:e64570. https://doi.org/10.1371/journal.pone.0064570.

21. Migita T, Ruiz S, Fornari A, Fiorentino M, Priolo C, Zadra G, Inazuka F, Grisanzio C, Palescandolo E, Shin E, Fiore C, Xie W, Kung AL, et al. Fatty acid synthase: a metabolic enzyme and candidate oncogene in prostate cancer. J Natl Cancer Inst. 2009; 101:519-32. https://doi.org/10.1093/jnci/ djp030.

22. Shah US, Dhir R, Gollin SM, Chandran UR, Lewis D, Acquafondata M, Pflug BR. Fatty acid synthase gene overexpression and copy number gain in prostate adenocarcinoma. Hum Pathol. 2006; 37:401-09. https:// doi.org/10.1016/j.humpath.2005.11.022.

23. Hamada S, Horiguchi A, Kuroda K, Ito K, Asano T, Miyai $\mathrm{K}$, Iwaya K. Elevated fatty acid synthase expression in prostate needle biopsy cores predicts upgraded Gleason score in radical prostatectomy specimens. Prostate. 2014; 74:90-96. https://doi.org/10.1002/pros.22732.

24. Duijvesz D, Burnum-Johnson KE, Gritsenko MA, Hoogland AM, Vredenbregt-van den Berg MS, Willemsen R, Luider T, Paša-Tolić L, Jenster G. Proteomic profiling of exosomes leads to the identification of novel biomarkers for prostate cancer. PLoS One. 2013; 8:e82589. https://doi. org/10.1371/journal.pone.0082589.

25. Chen HW, Chang YF, Chuang HY, Tai WT, Hwang JJ. Targeted therapy with fatty acid synthase inhibitors in a human prostate carcinoma LNCaP/tk-luc-bearing animal model. Prostate Cancer Prostatic Dis. 2012; 15:260-4. https://doi.org/10.1038/pcan.2012.15.

26. Huang M, Koizumi A, Narita S, Inoue T, Tsuchiya N, Nakanishi H, Numakura K, Tsuruta H, Saito M, Satoh S, Nanjo H, Sasaki T, Habuchi T. Diet-induced alteration of fatty acid synthase in prostate cancer progression. Oncogenesis. 2016; 5:e195. https://doi.org/10.1038/ oncsis.2015.42.

27. Sadowski MC, Pouwer RH, Gunter JH, Lubik AA, Quinn RJ, Nelson CC. The fatty acid synthase inhibitor triclosan: repurposing an anti-microbial agent for targeting prostate cancer. Oncotarget. 2014; 5:9362-81. https://doi. org/10.18632/oncotarget.2433.

28. Wen S, Niu Y, Lee SO, Yeh S, Shang Z, Gao H, Li Y, Chou F, Chang C. Targeting fatty acid synthase with ASC-J9 suppresses proliferation and invasion of prostate cancer cells. Mol Carcinog. 2016; 55:2278-90. https://doi. org/10.1002/mc.22468.

29. Vainio P, Lehtinen L, Mirtti T, Hilvo M, Seppänen-Laakso T, Virtanen J, Sankila A, Nordling S, Lundin J, Rannikko A, Orešič M, Kallioniemi O, Iljin K. Phospholipase PLA2G7, associated with aggressive prostate cancer, promotes prostate cancer cell migration and invasion and is inhibited by statins. Oncotarget. 2011; 2:1176-90. https:// doi.org/10.18632/oncotarget.397.

30. Patel MI, Singh J, Niknami M, Kurek C, Yao M, Lu S, Maclean F, King NJ, Gelb MH, Scott KF, Russell PJ, Boulas J, Dong Q. Cytosolic phospholipase A2- $\alpha$ : a potential therapeutic target for prostate cancer. Clin Cancer Res. 2008; 14:8070-79. https://doi.org/10.1158/1078-0432. CCR-08-0566.

31. Vainio P, Gupta S, Ketola K, Mirtti T, Mpindi JP, Kohonen P, Fey V, Perälä M, Smit F, Verhaegh G, Schalken J, Alanen KA, Kallioniemi O, Iljin K. Arachidonic acid pathway members PLA2G7, HPGD, EPHX2, and CYP4F8 identified as putative novel therapeutic targets in prostate cancer. Am J Pathol. 2011; 178:525-36. https://doi.org/10.1016/j. ajpath.2010.10.002.

32. Cano LQ, Lavery DN, Sin S, Spanjaard E, Brooke GN, Tilman JD, Abroaf A, Gaughan L, Robson CN, Heer R, Mauri F, de Rooij J, Driouch K, Bevan CL. The co-chaperone $\mathrm{p} 23$ promotes prostate cancer motility and metastasis. Mol Oncol. 2015; 9:295-308. https://doi. org/10.1016/j.molonc.2014.08.014.

33. Reebye V, Querol Cano L, Lavery DN, Brooke GN, Powell SM, Chotai D, Walker MM, Whitaker HC, Wait R, Hurst HC, Bevan CL. Role of the HSP90-associated cochaperone p23 in enhancing activity of the androgen receptor and significance for prostate cancer. Mol Endocrinol. 2012; 26:1694-706. https://doi.org/10.1210/me.2012-1056.

34. Ahram M, Best CJ, Flaig MJ, Gillespie JW, Leiva IM, Chuaqui RF, Zhou G, Shu H, Duray PH, Linehan WM, Raffeld M, Ornstein DK, Zhao Y, et al. Proteomic analysis of human prostate cancer. Mol Carcinog. 2002; 33:9-15. https://doi.org/10.1002/mc.10019.

35. Xian ZY, Liu JM, Chen QK, Chen HZ, Ye CJ, Xue J, Yang HQ, Li JL, Liu XF, Kuang SJ. Inhibition of LDHA suppresses tumor progression in prostate cancer. Tumour Biol. 2015; 36:8093-100. https://doi.org/10.1007/ s13277-015-3540-x.

36. Watson DG, Tonelli F, Alossaimi M, Williamson L, Chan E, Gorshkova I, Berdyshev E, Bittman R, Pyne NJ, Pyne S. The roles of sphingosine kinases 1 and 2 in regulating the Warburg effect in prostate cancer cells. Cell Signal. 2013; 25:1011-17. https://doi.org/10.1016/j.cellsig.2013.01.002. 
37. Boormans JL, Korsten H, Ziel-van der Made AJ, van Leenders GJ, de Vos CV, Jenster G, Trapman J. Identification of TDRD1 as a direct target gene of ERG in primary prostate cancer. Int J Cancer. 2013; 133:335-45. https://doi.org/10.1002/ijc.28025.

38. Böttcher R, Hoogland AM, Dits N, Verhoef EI, Kweldam C, Waranecki P, Bangma CH, van Leenders GJ, Jenster G. Novel long non-coding RNAs are specific diagnostic and prognostic markers for prostate cancer. Oncotarget. 2015; 6:4036-50. https://doi.org/10.18632/oncotarget.2879.

39. Roobol MJ, Kirkels WJ, Schröder FH. Features and preliminary results of the Dutch centre of the ERSPC (Rotterdam, the Netherlands). BJU Int. 2003 (Suppl 2); 92:48-54. https://doi.org/10.1111/j.1464-410X.2003.04390.x.

40. Schröder FH, Hugosson J, Roobol MJ, Tammela TL, Ciatto S, Nelen V, Kwiatkowski M, Lujan M, Lilja H, Zappa M, Denis LJ, Recker F, Berenguer A, et al, and ERSPC Investigators. Screening and prostate-cancer mortality in a randomized European study. N Engl J Med. 2009; 360:1320-28. https://doi.org/10.1056/NEJMoa0810084.

41. Hoogland AM, Jenster G, van Weerden WM, Trapman J, van der Kwast T, Roobol MJ, Schröder FH, Wildhagen MF, van Leenders GJ. ERG immunohistochemistry is not predictive for PSA recurrence, local recurrence or overall survival after radical prostatectomy for prostate cancer. Mod Pathol. 2012; 25:471-79. https://doi.org/10.1038/ modpathol.2011.176.

42. IJsselstijn L, Stoop MP, Stingl C, Sillevis Smitt PA, Luider TM, Dekker LJ. Comparative study of targeted and labelfree mass spectrometry methods for protein quantification. J Proteome Res. 2013; 12:2005-11. https://doi.org/10.1021/ pr301221f.
43. Singh V, Stoop MP, Stingl C, Luitwieler RL, Dekker LJ, van Duijn MM, Kreft KL, Luider TM, Hintzen RQ. Cerebrospinal-fluid-derived immunoglobulin $\mathrm{G}$ of different multiple sclerosis patients shares mutated sequences in complementarity determining regions. Mol Cell Proteomics. 2013; 12:3924-34. https://doi.org/10.1074/ mcp.M113.030346.

44. Tyanova S, Temu T, Cox J. The MaxQuant computational platform for mass spectrometry-based shotgun proteomics. Nat Protoc. 2016; 11:2301-19. https://doi.org/10.1038/ nprot.2016.136.

45. Cox J, Neuhauser N, Michalski A, Scheltema RA, Olsen JV, Mann M. Andromeda: a peptide search engine integrated into the MaxQuant environment. J Proteome Res. 2011; 10:1794-805. https://doi.org/10.1021/pr101065j.

46. van Leenders GJ, Boormans JL, Vissers CJ, Hoogland AM, Bressers AA, Furusato B, Trapman J. Antibody EPR3864 is specific for ERG genomic fusions in prostate cancer: implications for pathological practice. Mod Pathol. 2011; 24:1128-38. https://doi.org/10.1038/modpathol.2011.65.

47. Hoogland AM, Verhoef EI, Roobol MJ, Schröder FH, Wildhagen MF, van der Kwast TH, Jenster G, van Leenders GJ. Validation of stem cell markers in clinical prostate cancer: $\alpha 6$-integrin is predictive for non-aggressive disease. Prostate. 2014; 74:488-96. https://doi.org/10.1002/ pros. 22768 .

48. Tyanova S, Temu T, Sinitcyn P, Carlson A, Hein MY, Geiger T, Mann M, Cox J. The Perseus computational platform for comprehensive analysis of (prote)omics data. Nat Methods. 2016; 13:731-40. https://doi.org/10.1038/nmeth.3901. 